\title{
Vuorovaikutuksen rakentumisen syvällinen ymmärtäminen auttaa tunnistamaan matematiikan oppimista edistäviä vuorovaikutustekijöitä
}

\author{
Anniina Kämäräinen
}

\begin{abstract}
Viittausohje:
Kämäräinen, A. (2021). Vuorovaikutuksen rakentumisen syvällinen ymmärtäminen auttaa tunnistamaan matematiikan oppimista edistäviä vuorovaikutustekijöitä. Prologi - Viestinnän ja vuorovaikutuksen tieteellinen aikakauslehti, 17(1), 48-54. https://doi.org/10.33352/prlg.107319

To cite this article:

Kämäräinen, A. (2021). Vuorovaikutuksen rakentumisen syvällinen ymmärtäminen auttaa tunnistamaan matematiikan oppimista edistäviä vuorovaikutustekijöitä [In-depth understanding how interaction is constructed helps us identify the elements that enhance interactive learning in mathematics]. PrologiJournal of Communication and Social Interaction, 17(1), 48-54. https://doi.org/10.33352/prlg.107319
\end{abstract}

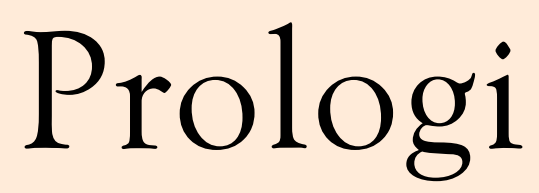

\section{- Viestinnän ja vuorovaikutuksen tieteellinen aikakauslehti journal.fi/prologi/}

ruotsiksi: Prologi - Tidskrift för Kommunikation och Social Interaktion englanniksi: Prologi - Journal of Communication and Social Interaction

Julkaisija: Prologos ry.

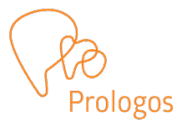

Avoin julkaisu / Open Access

ISSN 2342-3684 / verkko

ISSN 1795-7613 / painettu versio 


\title{
Lectio Praecursoria
}

Prologi, 17(1)

$48-54$

https://doi.org/10.33352/prlg.107319

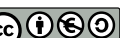

CC BY-NC-SA 4.0

\section{Vuorovaikutuksen rakentumisen syvällinen}

ymmärtäminen auttaa tunnistamaan

\section{matematiikan oppimista edistäviä}

\section{vuorovaikutustekijöitä}

\author{
Anniina Kämäräinen \\ $\mathrm{KT}$, yliopisto-opettaja \\ Itä-Suomen yliopisto \\ anniina.kamarainen@uef.fi
}

vastaanotettu 30.3. / hyväksytty 8.4. / julkaistu 21.6.2021

ASIASANAT: oppilaskeskeinen oppiminen, vertaisoppiminen, sosiaalinen vuorovaikutus, matematiikka, keskustelunanalyysi

Kasvatustieteen maisteri Anniina Kämäräisen erityispedagogiikan alaan kuuluva väitöskirja Oppilaskeskeisten matematiikan oppituntien sosiaalisen arkkitehtuurin rakentuminen tarkastettiin 26.02.2021 Itä-Suomen yliopiston filosofisessa tiedekunnassa. Vastaväittäjänä tilaisuudessa toimi dosentti Tanja Vehkakoski Jyväskylän yliopistosta ja kustoksena professori Eija Kärnä Itä-Suomen yliopistosta.

Väitöskirja on luettavissa verkossa osoitteessa http://urn.fi/URN:ISBN:978-952-61-3711-7 
"Tulevaisuuden työntekijän täytyy osata ajatella luovasti ja kriittisesti sekä ratkaista ongelmia. Ongelmia ratkotaan tiimeissä tai ryhmissä, ja siksi työntekijän on hyvä osata myös vuorovaikutustaitoja sekä tunnetaitoja, kuten empatiaa.” Tällaisia kuvauksia eri alojen tutkijat tuottivat, kun heiltä kysyttiin YLE Radion tuottamassa ohjelmassa Tiedeykkönen (12.04.2019), millaisia taitoja tulevaisuuden työelämä edellyttää työntekijöiltä.

Työelämän nopeatempoinen muuttuminen vaikuttaa voimakkaasti myös peruskouluun kohdistuviin uudistumisvaatimuksiin. Syksyllä 2016 käyttöön otettu perusopetuksen opetussuunnitelma vastaa monilla tavoin tähän vaatimukseen. Opetussuunnitelmassa todetaan, että "oppiminen ymmärretään yksilölliseksi ja yhteisölliseksi tietojen ja taitojen rakennusprosessiksi, jonka kautta syntyy kulttuurinen osallisuus". Opetussuunnitelmauudistuksen keskeisenä tavoitteena on siis vahvistaa oppilaan aktiivisuutta. Tavoitteena on myös lisätä opiskelun merkityksellisyyttä ja mahdollistaa onnistumisen kokemukset jokaiselle oppilaalle. Kouluissa lapsia ja nuoria ohjataan ottamaan vastuuta opiskelustaan ja jokaista oppilasta tuetaan opinnoissaan.

Työelämän muutosten ohella perusopetusta uudistaa inkluusioperiaatteeseen nojaava kehittämistyö. Inklusiivisen ajattelun ytimessä on yhdenvertainen ja esteetön, kaikki kansalaiset osallistava yhteiskunta. Inklusiivisen perusopetuksen tavoitteena on, että oppilasta ei eroteta toiseen kouluun tai luokkaan esimerkiksi vammaisuuden perusteella. Sen sijaan kaikille oppijoille pyritään tarjoamaan täydet mahdollisuudet osallistua omien oppimisedellytystensä mukaisesti opetukseen ja menestyä opinnoissaan omassa lähikoulussaan (Nilholm, 2020).
Keväällä 2021 inkluusio on herättänyt jälleen vilkasta keskustelua mediassa. On esitetty ajatuksia inkluusion epäonnistumisesta ja tarpeesta sen kriittiseen tarkasteluun. Kriittistä tarkastelua ja keskustelua tarvitaankin. Tilannetta on kuitenkin lähestytty jälleen perinteisestä näkökulmasta: tukea tarvitseva oppilas on puheissa esitetty ongelmana, joka ratkaistaan siirtämällä oppilas pois ryhmästä. Keskusteluun on ilahduttavasti osallistunut myös toisenlaisia ääniä, jotka ovat suuntautuneet tarkastelemaan yhteiskuntaa, sen instituutioita ja yhteisöjä.

Inklusiivisen opetuksen kehittämistyötä tuleekin tehdä ennen kaikkea yhteisöllisestä näkökulmasta niin yhteiskunnan, koulun kuin luokan toimintakulttuurin tasolla. Koulun ja luokan tasolla huomio tulee kiinnittää siihen, miten jokaisen oppilaan sosiaalinen osallistaminen toteutuu arkisissa käytännöissä. Yhtenä lähestymistapana on tutkia, millaiset vuorovaikutuskäytänteet edistävät tai heikentävät oppilaan osallistumista oppituntien aikana. Väitöstutkimukseni perustuu tällä tasolla tapahtuvaan oppituntien vuorovaikutuskäytänteiden tarkasteluun.

\section{Oppilaskeskeiset opetusmenetelmät yleistyvät}

Perusopetuksen toimintakulttuurin uudistumistarve näkyy oppilaskeskeisten opetusmenetelmien yleistymisenä. Oppilaskeskeisen opetuksen suunnittelussa opettaja yleensä määrittää oppilaiden koulutukselliset tarpeet tuottamalla oppimista tukevaa materiaalia ja suunnitelmia. Samalla hän suunnittelee toimintaa oppilaasta käsin pohtimalla, mikä olisi paras tapa saada oppilas ajattelemaan omaa oppimistaan. Oppilaskeskeisillä tunneilla oppilailla on tavallisesti suurempi autonomia omasta toiminnastaan sekä mahdollisuus valita oppimis- 
kohteet ja työskentelytavat. Opettaja osallistuu tuntityöskentelyyn oppilaiden tarpeiden mukaisesti ohjaamalla, tukemalla ja fasilitoimalla yksilön tai ryhmän työskentelyä (Neumann, 2013).

Vaikka oppilaskeskeisten menetelmien edut on yleisesti tunnistettu ja tunnustettu tutkimuksen ja opetussuunnitelmien tasolla, kouluarjessa käydään edelleen kriittistäkin keskustelua kyseisten opetusmenetelmien hyödyistä. Myös oppilaat kertovat usein kokevansa esimerkiksi erilaiset ryhmätyöskentelymuodot tehottomiksi, jopa täysin hyödyttömiksi. Saman ilmiön olen ajoittain havainnut korkeakouluopiskelijoiden kanssa toimiessani. Keskeisimpiä ilmiön taustalla vaikuttavia syitä ovat varmasti vanhan ja uuden kulttuurin väliset niin osallistujien rooleja kuin työskentelytapoja koskevat merkittävät erot.

Pitkään vallalla olleen toimintakulttuurin muutostyö edellyttää tietoista, määrätietoista ja yhteisöllistä uudistamistyötä. Se edellyttää vallalla olevan ja uuden toimintakulttuurin sulauttamista uudenlaiseksi yhtenäiseksi toimintakulttuuriksi, joka varioi joustavasti ja tarkoituksenmukaisesti sekä opettajajohtoisempia että oppilaskeskeisiä menetelmiä. Uskon, että oppilaskeskeisten menetelmien kyseenalaistamisen aika alkaa olla ohi. Kyseenalaistamisen sijaan huomio tulee nyt kohdistaa niihin tekijöihin, jotka edistävät tai hidastavat muutosta kohti aidosti oppilaskeskeistä, jokaisen oppijan osallistavaa sekä tulevaisuuden työelämään valmistavaa toimintakulttuuria.

\section{Vuorovaikutteinen matematiikan opiskelu}

Lukijalle ei varmaan vielä ole selvinnyt, miksi valitsin tutkimuksen kohteeksi juuri matematii- kan oppitunnit yläkoulussa. Matematiikan opetus on perustunut perinteisesti hyvin opettajajohtoiseen ja yksilötyöskentelyä korostavaan opetustapaan. Minua tämä ilmiö mietitytti jo silloin, kun itse kävin peruskoulua. Koin matematiikan opiskelun usein tylsäksi, lähinnä erilaisten algoritmien mekaaniseksi toistamiseksi. Yksin työskentely ei tukenut omalla kohdallani syvemmän ymmärryksen muodostumista matemaattisista ilmiöistä.

Peruskouluaikaiset kokemukseni toimivat merkittävänä pontimena luokanopettajakoulutukseen hakeutumiselle. Opintojen aikana päädyin vaihtamaan pääaineeni erityispedagogiikkaan, sillä näin sen tarjoavan syvempää osaamista sekä keinoja moninaisten oppijoiden opettamiseen ja oppimisen tukemiseen. Erityisopettajaopintojen aikana aloin pohtia matematiikan opetuksessa vallitsevaa yksin työskentelyn kulttuuria niiden oppijoiden näkökulmasta, joilla on matemaattisia ja kielellisiä oppimisvaikeuksia. Pohdin, miten lähes ensimmäisen luokan alusta lähtien pitkälti matemaattiseen symbolikieleen nojaava opiskelutapa vaikuttaa heidän oppimiseensa.

Koulumatematiikka pitää sisällään useita kieliä. Näitä ovat taktiilinen toiminnan kieli (matematiikkavälineiden käsittely), luonnollinen matematiikan kieli (sis. matemaattiset termit), kuviokieli (sis. matemaattiset kuviot, kuten murtokakut) sekä symbolikieli (sis. numerot ja muut symbolit). Jos emme opettele puhumaan näitä kieliä, eli emme opi kielentämään matematiikkaa, voivat eri kielet jäädä hyvinkin irrallisiksi toisistaan (Joutsenlahti \& Tossavainen, 2018). Jos kielten välistä yhteyttä ei muodostu, matemaattisten ilmiöiden kognitiivinen prosessointi ja syvemmän ymmärryksen muodostuminen vaikeutuu. Voiko jopa olla niin, että joillakin opetusmenetelmillä tuotamme tahattomasti lisää oppimisen haasteita? 
Tutkimukset osoittavat, että erityisesti ne oppilaat, joilla on matemaattisia oppimisvaikeuksia sekä kielellisiä vaikeuksia hyötyvät aktiiviseen kielenkäyttöön kannustavista opetusmenetelmistä (Riccomini ym, 2015). Vuorovaikutteinen toimintakulttuuri ja aktiivinen yhdessä tekeminen siis tukevat matematiikan kielten omaksumista ja käyttöä.

Oppilaan aktiivisuuden merkitys korostuu ja näkyy myös opetussuunnitelmaan kirjatuissa matematiikan oppisisällöissä ja tavoitteissa. Opetussuunnitelman tavoitteissa kuvataan, kuinka matemaattisia ongelmia matematisoidaan, ratkaistaan ja tulkitaan yksin ja yhdessä. Lisäksi matematiikan opetuksen tavoitteena on kehittää oppilaiden viestintä-, vuorovaikutus- ja yhteistyötaitoja sekä vastuun ottamista omasta oppimisesta.

Yksilötyöskentelyä korostava toimintakulttuuri on kuitenkin edelleen vallalla erityisesti yläkoulun matematiikan oppitunneilla. Lisäksi oppilaat kokevat oppitunnit vain harvoin tunnetasolla sitouttaviksi, positiivisiksi tai innostaviksi. Mitkä tekijät mahtavat vaikuttaa siihen, että perinteinen matematiikan opetus pitää edelleen pintansa? Yhtenä taustalla vaikuttavana tekijänä on yksilön kognitiiviseen toimintaan keskittynyt tutkimusperinne. Lisäksi tutkimusten mukaan matematiikan opettajat kokevat vuorovaikutteisten työskentelytapojen toteuttamisen haastaviksi.

Opettajajohtoiseen ja yksilötyöskentelyn perinteeseen tottuneille oppilaille vuorovaikutteinen matematiikan opiskelu voikin tuntua hankalalta. Matematiikan oppituntien vuorovaikutuskäytänteitä näkyväksi tekevä tutkimus auttaa hahmottamaan vuorovaikutuksen yksityiskohtaista rakentumista (Ingram 2018). Siten vuorovaikutustutkimuksen avulla voidaan selvittää, millaisia valmiuksia ja taitoja opetuksen uudis- taminen edellyttää niin opettajilta kuin oppilailta, ja millaisten taitojen vahvistamiseen on siten tarpeellista kiinnittää tietoisesti huomiota.

\section{Vuorovaikutuksen rakentuminen oppitunneilla}

Väitöstutkimuksessani tarkastelin oppilaskeskeisyyteen ja minimaaliseen opettajan ohjeistukseen perustuneiden matematiikan oppituntien vuorovaikutuksen rakentumista. Tutkimusaineisto koostui yhdeksännen luokan matematiikan oppitunneilla kerätyistä ääni- ja videonauhoituksista. Tutkimusaineisto kerättiin kahdessa vaiheessa ja aineistonkeruuseen osallistui yhteensä 41 oppilasta.

Oppituntien opetuskokonaisuuden aiheena oli suoran yhtälö. Uutta aihetta opiskeltiin opettajan etukäteen laatimien ongelmatehtävien sekä opetusteknologian avulla. Oppilaat työskentelivät pääsääntöisesti pienryhmissä. Opiskelutilanteet poikkesivat kuitenkin perinteisestä ryhmätyöskentelystä, sillä oppilailla oli vastuu päättää myös työskentelyn käynnistämisestä, rytmittämisestä ja ongelmatehtävien valinnasta.

Ensimmäisessä osatutkimuksessa muodostettiin diskurssianalyysin keinoin yleiskuva oppituntien keskustelutyypeistä. Oppitunneilla esiintyi sekä opettajan ja oppilaiden välisiä että oppilaiden keskinäisiä keskusteluja. Opettajan ja oppilaiden välillä rakentui neuvoa-antavia ja dialogisia keskusteluja. Oppilaiden keskinäisessä vuorovaikutuksessa esiintyneitä keskustelutyyppejä taas olivat organisoiva, argumentoiva, kollaboratiivinen ja ohjauksellinen keskustelu.

Oppitunneilla opettaja kutsuttiin ryhmäkeskusteluun mukaan, kun oppijat tarvitsivat apua tehtävän ymmärtämisessä tai teknologian käy- 
tössä. Avunpyyntöä seurasi yleensä lyhyt neuvoa-antava keskustelu. Opettajan ja oppilaiden välinen dialoginen keskustelu oli oppilaita osallistava ja heidän ajatteluaan aktivoiva keskustelumuoto. Opettaja esitti erilaisia oppilaiden tietämystä kartoittavia sekä ohjaavia kysymyksiä. Kysymykset kannustivat oppilaita kielentämään omaa ajatteluaan. Lisäksi opettaja toisti, uudelleen muotoili ja vahvisti oppilaiden ilmauksia. Opettaja myös haastoi oppilaan ajattelua esittämällä eriäviä näkemyksiä sekä muodosti yhteyksiä oppilaiden ilmausten välille. Erityisen merkittävä havainto oli, että dialoginen keskustelu antoi usein sytykkeen oppilaiden keskinäisen kollaboratiivisen keskustelun käynnistymiseen.

Seuraavissa osatutkimuksissa syvennyttiin keskustelunanalyysin tarjoamien työkalujen (Gardner, 2019; Heritage, 2012) avulla tarkastelemaan yksityiskohtaisesti kahta oppimisprosessin kannalta keskeistä vertaistyöskentelyn solmukohtaa. Näitä olivat (a) työskentelyn organisointi ja siirtymä seuraavaan opiskelutoimintaan sekä (b) oppimistilanteiden aikana vertaisten välillä havaitun tiedollisen eron ratkaiseminen. Erityisen kiinnostava havainto oli, että vertaiset olivat jatkuvasti suuntautuneet tarkkailemaan, ilmaisemaan ja käsittelemään omaa ja toisten opiskeltavaa aihetta koskevaa tietämystä. Tämä näkyi niin vertaistyöskentelyn organisointia kuin oppimistilanteita koskevien toimintajaksojen aikana.

Oppilaiden vertaistyöskentely käynnistyi useimmiten yhden oppilaan tehtäväehdotuksesta ja johti neuvottelun sekä yhteisen päätöksenteon kautta yhteiseen ongelmanratkaisuprosessiin. Jos taas vertaisten välille oli muodostunut pysyvä tiedollinen epäsymmetria, taitavampi oppilas saattoi tehdä itse päätöksen seuraavasta opiskelutoiminnasta ja vain ilmoitti sen vertaisilleen. Vertaiset vuorostaan, toisinaan vastalauseidenkin saattelemana, hyväksyivät päätöksen. Toisin sanoen ilmoitus kutsui vertaiset yhdessä työskentelyyn, mutta se ei mahdollistanut neuvottelua ja yhteistä päätöksentekoa. Aloitteentekijä oli saavuttanut ryhmässä tiedollisen auktoriteettiaseman, joka antoi hänelle oikeuden määrittää ryhmän työskentelyä.

Kolmas osatutkimus keskittyi oppimistilanteissa esiintyneisiin toimintajaksoihin, joiden aikana oppilaat suuntautuivat ratkaisemaan heidän välillään havaittua tiedollista eroa. Kahden aineistoesimerkin avulla havainnollistettiin sitä, miten erilaisten vuorovaikutustekojen avulla tietoero ratkaistaan riippuen siitä, luotsaako toimintaa enemmän vai vähemmän tietävän asemaan asettunut oppilas.

Ensimmäisessä esimerkissä vertaisryhmässä havaitun kulmakerrointa koskevan tietoeron ratkaisemista luotsasi enemmän tietävä oppilas. Oppilas hyödynsi opettajajohtoisille tunneille tyypillistä kolmiosaista opetussykliä, joka muodostuu opettajan kysymyksestä, oppilaan vastauksesta ja opettajan palautteesta. Oppilas siis omaksui ikään kuin perinteisen opettajan roolin ja määritti vuorovaikutuksen kulkua peruskoulun aikana tutuksi tullutta toimintatapaa hyödyntämällä. Hän esitti tenttaavia ja johdattelevia kysymyksiä sekä korjasi vertaisen virheellisiä vastauksia. Vertaisen toiminta rajautui kysymyksiin vastaamiseen.

Toisessa esimerkissä taas vähemmän tietävä oppilas oli aloitteellinen ja aktiivinen suoran yhtälöä koskevan tietoeron ratkaisija. Toimintajakson aikana oppilas peilasi omaa ymmärrystään taitavamman vertaisen tietämykseen. Oppilaan käyttämiä kielellisiä keinoja olivat vertaiselle esitetyt tietoa tai vahvistusta kartoittavat hakuja tarkistuskysymykset. Kysymykset saattoivat myös haastaa vertaisen esittämiä väitteitä, jos 
ne olivat ristiriidassa kysyjän sen hetkisen ymmärryksen kanssa. Vertaisen kysymykset aktivoivat taitavampaa oppilasta perustelemaan väitteitään. Siten molempien oppilaiden sen hetkinen ymmärrys ja tietäminen tulivat vuorovaikutuksessa näkyviksi ja yhdessä käsiteltäviksi.

Kaiken kaikkiaan tietoeron ratkaiseminen oli pitkä, mutta oppimisen kannalta hedelmällinen prosessi, kun molemmat oppilaat sanoittivat ja perustelivat ymmärrystään. Tietoero ratkesi, kun aktiivinen oppilas lopulta ilmaisi saavuttaneensa saman ymmärryksen vertaisen kanssa.

\section{Johtopäätökset}

Ensinnäkin tutkimus osoittaa, että vertaistyöskentelyn aikana oppijat voivat omaksua yhteiseen tiedonmuodostukseen tähtääviä ongelmanratkaisutaitoja. Tällainen yhteinen prosessointi tukee ymmärtävää oppimista.

Vertaisten välinen tiedollinen epäsymmetria hyödyttää parhaimmillaan kaikkien oppilaiden oppimista. Taitavampi oppija tarkastelee opiskeltavaa aihetta uudesta näkökulmasta ohjatessaan ja perustellessaan tietämystään vertaiselleen, joka taas saa selvennettyä ymmärrystään. Tulokset osoittivat kuitenkin, että ryhmään muodostunut pysyvä tietoero voi johtaa perinteistä opettajajohtoista tilannetta muistuttavaan toimintatapaan, jolloin taitava oppija ohjaa vertaisten työskentelyä kysymällä, neuvomalla ja virheitä korjaamalla. Taitavampi oppilas keskittyy siis jo omaksumansa tiedon opettamiseen. Vertaisen toiminta taas rajautuu vastaamiseen, jolloin hän ei välttämättä saa mahdollisuutta oman sen hetkisen ymmärryksen monipuoliseen kielentämiseen. Riskinä on, että työskentelytapa rajoittaa kaikkien osallistu- jien mahdollisuuksia aktiiviseen uuden tiedon prosessointiin.

Oppimisprosessin käynnistymisen ydin on, että oppilas ymmärtää, mitä jo ymmärtää ja mitä ei vielä ymmärrä. Ajattelua aktivoivat kysymykset ovat tehokkaimpia oppimisprosessin käynnistäjiä. Tutkimuksen tulokset osoittivat, että oppilaat osaavat esittää toisilleen erinomaisia kysymyksiä. Oppilaiden rohkaiseminen ongelmien yhteiseen pähkäilyyn, oman vaillinaisenkin ymmärryksen sanoittamiseen sekä väärinymmärrysten ja ristiriitojen yhteiseen ratkaisemiseen ovat syvälliseen ymmärtämiseen tähtäävän oppimisen avaintekijöitä.

Toiseksi tutkimustulokset viittaavat siihen, että opettajan merkitys on keskeinen oppilaskeskeisillä oppitunneilla. Opettaja havainnoi jatkuvasti ryhmiä ja tarvittaessa tuki yksittäisen oppilaan osallistumista sekä ryhmän työskentelyn käynnistymistä tai jatkumista.

Opettajan roolin muutos tuntityöskentelyn johtajasta sen havainnoijaksi ja ohjaajaksi on merkittävä. On luonnollista, että muutos voi aiheuttaa opettajissa epävarmuutta. Mitä tapahtuu, kun langat eivät olekaan oppitunnin alusta lähtien omissa hyppysissä, eikä opettaja siten voi ennakoida, mitä tunnilla tulee tapahtumaan? Vuorovaikutusilmiöiden tunnistaminen ja syvällinen ymmärtäminen auttaa oppilaiden työskentelyä tarkkailevaa opettajaa havaitsemaan oppilaiden välisessä vuorovaikutuksessa ne hetket, jolloin yksittäinen oppilas tai ryhmä voi tarvita ulkopuolista tukea.

Kaiken kaikkiaan oppilaskeskeiset opetusmenetelmät tarjoavat erinomaisen mahdollisuuden opiskeltavien ilmiöiden yhdessä ihmettelyyn. On syytä korostaa, ettei opettajalla tarvitse olla oppilaiden mahdollisiin avunpyyntöihin ja kysymyksiin valmiita vastauksia. Oppimisen 
kannalta tehokkaimpia keinoja ovat opettajan esittämät kysymykset, joiden muotoilussa on huomioitu oppilaan sen hetkinen ymmärrys. Tällaiset kysymykset aktivoivat, ohjaavat ja laajentavat oppilaan ajattelua.

Kolmas huomio on, että toimintakulttuurin uudistaminen oppilaskeskeiseksi edellyttää tietoista uudistustyötä. Tutkimus osoitti, että oppilailla on valmiuksia organisoida työskentelyä sekä ratkaista yhdessä matemaattisia ongelmia. Työskentelytavan tarjoama autonomia organisoida omaa ja ryhmän toimintaa aiheutti kuitenkin oppilaissa aluksi hämmennystä.

Vertaistyöskentelyn aikaiset tiedolliset ristiriitatilanteet taas johtivat ajoittain "eipäs juupas" -väittelyyn, jolloin oppilaat keskittyivät puolustamaan omaa ymmärrystään sen sijaan, että olisivat aktiivisesti pyrkineet ymmärtämään vertaisten väitteitä ja perusteluja. Tulokset vahvistavat aiempien, lähinnä alakoulussa tehtyjen tutkimusten havaintoja siitä, että korkeatasoinen yhdessä ajatteluun pyrkivä työskentely on vaativa tiedonmuodostuksen tapa.

Toimintakulttuurin uudistamista edesauttaa, jos opetus sisältää koulupolun alusta lähtien työskentelytaitojen tietoista ja tavoitteellista harjoittelua. Työskentelytaitoihin sisältyy erityisesti kyky kysyä, neuvotella, ihmetellä, sanoittaa ajatteluaan, esittää väitteitä ja vastaväitteitä sekä kyky tavoitella yhteisen ymmärryksen muodostumista. Kun yhdessä ihmettely ja epävarmuus tietämisestä asetetaan alusta lähtien oppituntien työskentelyn lähtökohdaksi, saavat myös inklusiivisissa ryhmissä opiskelevat kai- kenlaiset oppijat mahdollisuuden osallistua ja oppia yhdessä.

Millaiseksi oppituntien sosiaalinen arkkitehtuuri muotoutuisikaan oppilasryhmässä, jolle oppilaskeskeiset menetelmät ovat olleet luonnollinen osa koulupäiviä ensimmäisestä luokasta lähtien? Sellaisen ryhmän vuorovaikutustilanteita olisi arvokasta päästä tutkimaan lähemmin.

\section{Kirjallisuus}

Gardner, R. (2019). Classroom interaction research: The state of the art. Research on Language and Social Interaction, 52(3), 212-226.

https://doi.org/10.1080/08351813.2019.1631037

Heritage, J. (2012). Epistemics in action: Action formation and territories of knowledge. Research on Language and Social Interaction, 45(1), 1-29. https://doi.org/10.1080/08351813.2012.646684

Ingram, J. (2018). Moving forward with ethnomethodological approaches to analysing mathematics classroom interactions. ZDM, 50(6), 1065-1075. https://doi.org/10.1007/s11858-018-0951-3

Joutsenlahti, J. \& Tossavainen, T. (2018). Matemaattisen ajattelun kielentäminen ja siihen ohjaaminen koulussa. Teoksessa J. Joutsenlahti, H. Silfverberg \& P. Räsänen (toim.), Matematiikan opetus ja oppiminen (s. 410-430). Porvoo: Bookwell Oy.

Nilholm, C. (2020). Research about inclusive education in 2020 - How can we improve our theories in order to change practice? European Journal of Special Needs Education. https://doi.org/10.1080/08856257.2020.1754547

Riccomini, P., Smith, G., Hughes, E., \& Fries, K. (2015). The language of mathematics: The importance of teaching and learning mathematical vocabulary. Reading \& Writing Quarterly, 31(3), 235-252. https://doi.org/10.1080/10573569.2015.1030995

\section{TITLE AND KEYWORDS IN ENGLISH:}

\section{In-depth understanding how interaction is constructed helps us identify the elements that enhance interactive learning in mathematics}

KEYWORDS: student-centred learning, peer learning, social interaction, mathematics, conversation analysis 